\title{
Multilevel Inverter for AC Drives with Less Number of Swiches
}

\section{Laxmi Goswami}

\begin{abstract}
Multilevel inverter plays an important role at today's time. This gives us a good measure of voltage, reduces harmonic integrity, reduces energy loss and also gives us high levels of energy. The different types of topology that are produced takes reduce amount of power, voltage source and voltage switching as compared to traditional topology. This paper focuses on the variety of modes in the multilevel inverter, methods of modulation, voltage stress and how to eliminate the effect of total harmonic distortion. In the end the advantages and disadvantages of the review topology is concluded.
\end{abstract}

Keywords- multilevel inverter, ac drives, total harmonic distortion, voltage switching.

\section{INTRODUCTION}

"Multilevel inverters are the device that can be used to convert DC power to AC power at a variable frequency and change voltage". Scope of multi stage inverter arrive rapidly as a result of its reliability and high voltage applications [1],[2]. The capacitors, voltage source, diodes and semiconductor fast actuating switches are all combined makes a multilevel inverter [3], [4]. This decreases the total harmonic distortion, converts voltage and develops the waveform it describes as a sinusoidal form. The greatest benefits of multi-level inverter with respect to conventional inverting devices migrants experience low losses at high frequency and are very less effected by the harmonic distortion and low rate of change of voltage stress [5]. In Table I the comparison between the conventional inverter and multilevel inverter is shown.

The multilevel inverter takes pure dc voltage as an input and gives pure and smooth sinusoidal voltage waveform as an output. Further this sinusoidal output power is used for driving various types of ac motors. The main advantage of using multilevel inverter is that it provides stepping up of voltage from very low dc voltage to high ac voltage [6],[7].

\section{STUDY OF PROPOSED SYSTEM \& RESULTS}

Basically three topologies are shown in figure.1. fig1.(a) shows diode clamp multilevel inverter, fig.1(b) shows flying machine multilevel inveter and fig. 1 (c) shows cascaded $\mathrm{H}$ bridege multilevel inverter.

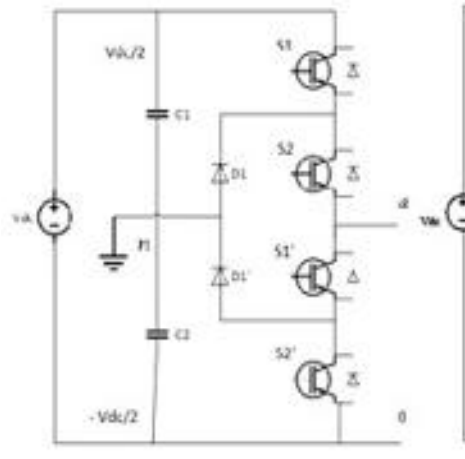

(4)
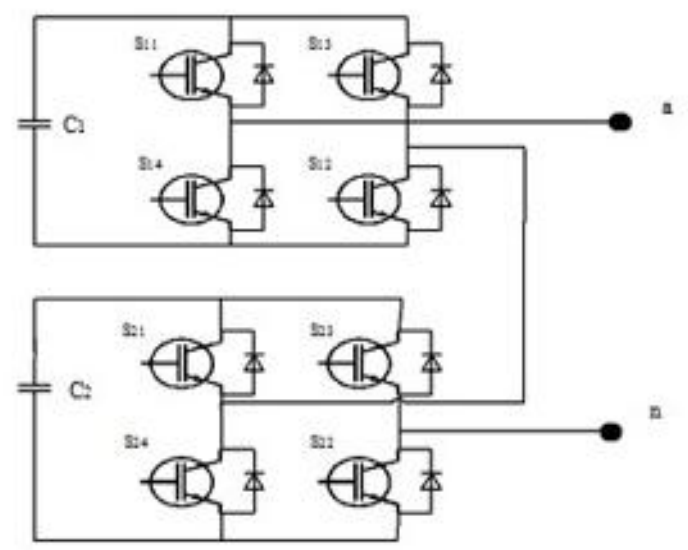

(c)

Fig. 1 Multilevel inverter topologies, (a) Diode Clamped MLI, (b) Flying Capacitor MLI, (c) Cascaded H-Bridge MLI

The topology suggested here i.e. multilevel inverter with diode clamped, cascaded h-bridge multilevel inverter and flywheel capacitor multilevel inverter. In $\mathrm{H}$ - bridge inverter is connected in series than it is known as cascaded H-bridge inverter [8]. The topology that was first introduced is diode clamp topology which consist of semiconductor switches, voltage sources and diodes [9]. This type of topology is helpful in reducing the voltage stress from the circuit. 
TABLE I: Comparison of conventional Inverter and Multilevel Inverter

\begin{tabular}{|l|l|l|}
\hline $\begin{array}{l}\text { Sl. } \\
\text { No. }\end{array}$ & $\begin{array}{l}\text { Conventional } \\
\text { inverter }\end{array}$ & Multilevel inverter \\
\hline 1. & $\begin{array}{l}\text { High rate of } \\
\text { change of } \\
\text { voltage }\end{array}$ & $\begin{array}{l}\text { Low rate of } \\
\text { change voltage }\end{array}$ \\
\hline 2. & Switching stress are high & Switching stress are low \\
\hline 3. & $\begin{array}{l}\text { Used for low voltage } \\
\text { application }\end{array}$ & $\begin{array}{l}\text { Used for high } \\
\text { voltage } \\
\text { application }\end{array}$ \\
\hline 4. & EMI are more & EMI are less \\
\hline 5. & High switching frequency & Low switching frequency \\
\hline 6. & Low power & $\begin{array}{l}\text { High power } \\
\text { application }\end{array}$ \\
\hline
\end{tabular}

Table. 1 shows the comparison between the conventional used inverter [10] and multilevel inverter. From comparison table it is concluded that the conventional inverters have high rate of change in voltage stress as compared to multilevel inverter [11], switching stress is high in conventional inverter and can be used only for low voltage application, wherein the multilevel inverter has low switching stress and is used for high voltage applications [12]. Restrictions on everything will give rise to negative impact instead of positive impact. At present there is too much sovereignty and there is a need to reduce the completeness and increase the size of the aviation. This paper is looking at these influences and trying to solve the problem of total harmonic distortion and voltage stress during switching.

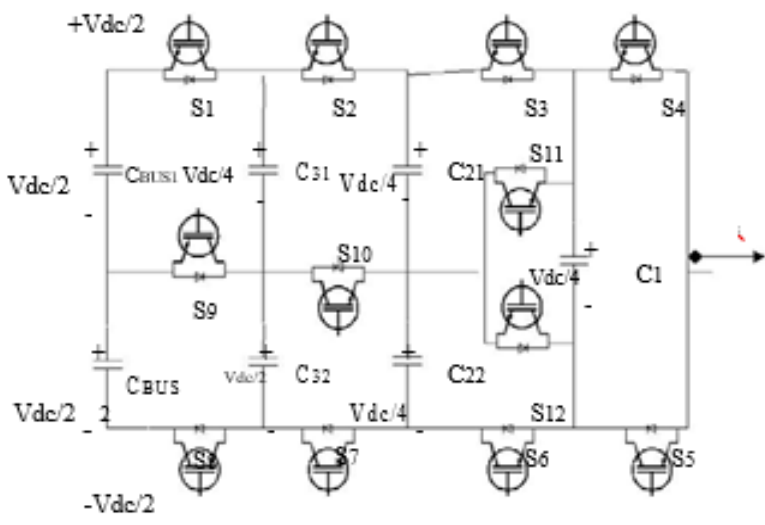

Fig. 2 Five level ANPC Topology
TABLE II: SWITCHING STATES OF THE NEW 5L-ANPC

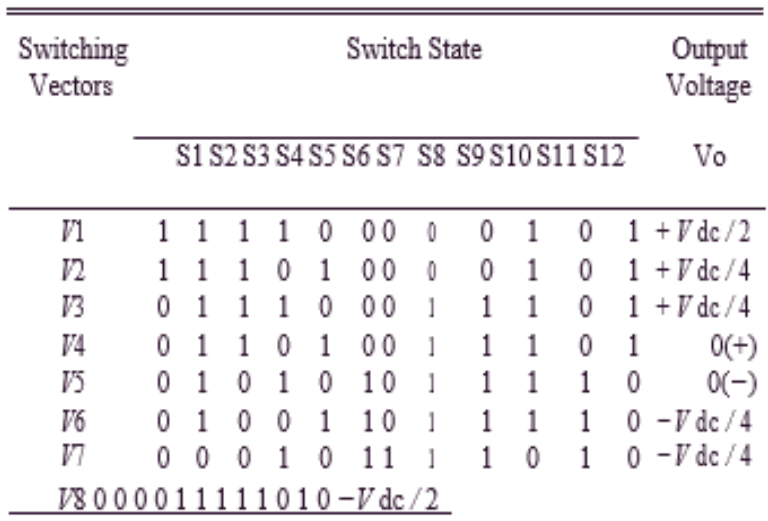

Figure.2 shows the five level Active Neutral Point Clamped multilevel inverter [13]. This inverter reduces the power loss and eliminates unbalance distribution condition. Table. 2 shows the switching state of five level inverter. The switching states table are shown the five level of voltages. In this inverter among five capacitors in five level, four are auxiliary capacitors and at $5^{\text {th }}$ level one big capacitor is used for the following purposes;

1. The unbalanced voltage and series connection of semiconductor devices are eliminated by this large capacitor.

2. It also minimizes the hardware requirement with reduced overvoltage at the time of commutation.

3. Smooth flow of current and avoiding blockage of voltage in the inverting circuit.

4. The advantage of auxiliary capacitor is that it protects the overvoltage from striking into the circuit.

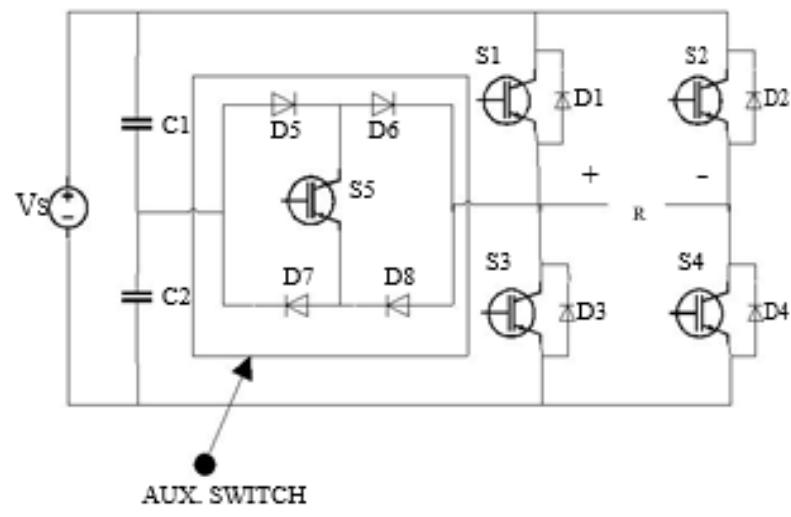

Fig.3 Auxiliary Switch Cascade H-Bridge Topology 
TABLE III: Switching Combinations Required to Generate Five Level Output Voltage Waveform

\begin{tabular}{|c|c|c|c|c|c|}
\hline S1 & S2 & S3 & S4 & S5 & VR \\
\hline ON & OFF & OFF & ON & OFF & Vs \\
\hline OFF & OFF & OFF & ON & ON & Vs/2 \\
\hline OFF & OFF & ON & ON & OFF & 0 \\
\hline OFF & ON & OFF & OFF & ON & $-\mathrm{Vs} / 2$ \\
\hline ON & OFF & OFF & ON & OFF & $-\mathrm{Vs}$ \\
\hline
\end{tabular}

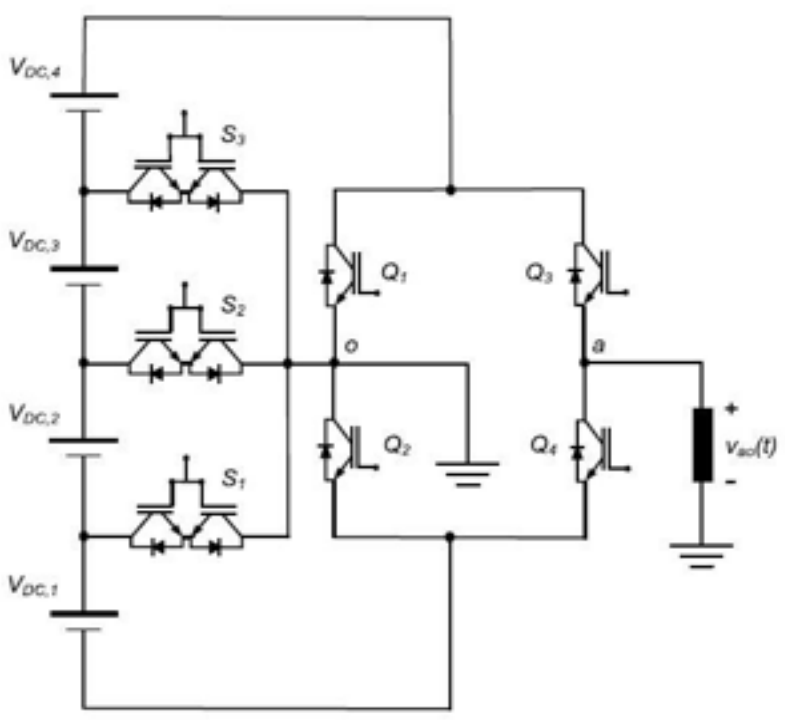

Fig. 4 T-Type Inverter Topology

TABLE IV: Switching Scheme for Seven Level 5 Switch Topology

\begin{tabular}{|c|c|c|c|c|c|c|}
\hline $\begin{array}{c}\text { S1. } \\
\text { No }\end{array}$ & S1 & S2 & S3 & S4 & S5 & $\begin{array}{c}\text { Output } \\
\text { Voltage }\end{array}$ \\
\hline 1 & OFF & OFF & ON & OFF & ON & + Vdc \\
\hline 2 & OFF & ON & OFF & OFF & ON & +2 Vdc \\
\hline 3 & ON & OFF & OFF & OFF & ON & +3 Vdc \\
\hline 4 & OFF & OFF & OFF & OFF & OFF & 0 \\
\hline 5 & ON & OFF & OFF & ON & OFF & - Vdc \\
\hline 6 & OFF & ON & OFF & ON & OFF & -2 Vdc \\
\hline 7 & OFF & OFF & ON & ON & OFF & -3 Vdc \\
\hline
\end{tabular}

This paper proposes several types of topologies with different switching mode of operations. Fig.4 shows the seven level five switch multilevel inverter which uses reduced number of switches for reducing the power loss distribution. This inverter uses bidirectional switch. In total it uses four dc voltage supply source and 5 bidirectional on off switches. The main advantage of using seven level inverters is that it uses reduced number of switches to give same output as compare to other but eliminates switching power loss.

\section{CONCLUSION}

This paper deals with the study of several types of multilevel inverters used for driving ac motors. Various merits and demerits of different inverter are noted. It is concluded that by the application of five level Active Neutral Point Clamped multilevel inverter the flow of overvoltage is eliminated. Employment of cascaded $\mathrm{H}$ bridge multilevel inverter reduces the power losses in switches.

\section{REFERENCES}

1. E. Burguete, J. Lopez, and M. Zabaleta, "A New FiveLevel Active Neutral-Point-Clamped Converter with Reduced Overvoltages," IEEE Trans. Ind. Electron., 2016.

2. Z. Liu, Y. Wang, G. Tan, H. Li, and Y. Zhang, "A Nove SVPWM Algorithm for Five-Level Active Neutral-PointClamped Converter," IEEE Trans. Power Electron., 2016.

3. E. Babaei, S. Laali, and Z. Bayat, "A single-phase cascaded multilevel inverter based on a new basic unit with reduced number of power switches," IEEE Trans. Ind. Electron., 2015.

4. E. Najafi and A. H. M. Yatim, "Design and implementation of a new multilevel inverter topology," IEEE Trans. Ind. Electron., 2012

5. M. Patra, M. G. Majumder, B. Das, A. Chakraborty, and P. R. Kasari, "A new modular multilevel converter topology with reduced number of power electronic components," in Proceedings of 2017 International Conference on Innovations in Information, Embedded and Communication Systems, ICIIECS 2017, 2018.

6. E. Babaei, S. Laali, and S. Alilu, "Cascaded multilevel inverter with series connection of novel H-bridge basic units," IEEE Trans. Ind. Electron., 2014.

7. M. D. Siddique et al., "Asymmetrical Multilevel Inverte Topology with Reduced Number of Components," in Proceedings of 2018 IEEE International Conference on Power Electronics, Drives and Energy Systems, PEDES 2018, 2019.

8. B. Xiao, L. Hang, J. Mei, C. Riley, L. M. Tolbert, and B Ozpineci, "Modular Cascaded H-Bridge Multilevel PV Inverter with Distributed MPPT for Grid-Connected Applications," IEEE Trans. Ind. Appl., 2015.

9. K. K. Gupta and S. Jain, "Comprehensive review of a recently proposed multilevel inverter," IET Power Electron., 2014.

10. A. Dubey and A. K. Bansal, "Cascaded H-bridge multilevel inverter," Int. J. Control Theory Appl., 2016.

11. K. Sivakumar, A. Das, R. Ramchand, C. Patel, and K. Gopakumar, "A hybrid multilevel inverter topology for an open-end winding induction-motor drive using twolevel inverters in series with a capacitor-fed H-bridge cell," IEEE Trans. Ind. Electron., 2010.

12. I. Colak, E. Kabalci, and R. Bayindir, "Review of multilevel voltage source inverter topologies and control schemes," Energy Convers. Manag., 2011.

13. J. Rodriguez, S. Bernet, P. K. Steimer, and I. E. Lizama, "A survey on neutral-point-clamped inverters," IEEE Transactions on Industrial Electronics. 2010 